\title{
Reproductive performance of fixed-time artificial insemination in swine and factors for the technology success
}

\section{Monike Quirino $^{1}$ iD Ana Raquel Almeida Pinheiro ${ }^{1}$ (D) Joabel Tonellotto dos Santos ${ }^{2}$ Rafael da Rosa Ulguim ${ }^{1}$ iD Ana Paula Gonçalves Mellagi ${ }^{1}$ iD Fernando Pandolfo Bortolozzo $^{{ }^{*}}$ (iD)}

${ }_{1}^{1}$ Setor de Suínos, Departamento de Medicina Animal, Faculdade de Veterinária, Universidade Federal do Rio Grande do Sul (UFRGS), Porto Alegre, RS, Brasil, 91540-000. E-mail: fpbortol@ufrgs.br. "Corresponding author.

${ }^{2}$ Instituto Federal de Educação (IF), Ciência e Tecnologia Farroupilha, Frederico Westphalen, RS, Brasil.

ABSTRACT: Fixed-time artificial insemination (FTAI) is a reproductive technology that aids in obtaining an appropriate time to perform single artificial insemination (AI), thus reducing the number of inseminations per sow bred. FTAI protocols can either be based on estrus detection or day of weaning, aiming to synchronize ovulation using ovulation inducers. The protocols involving estrus detection usually employ porcine luteinizing hormone ( $p L H)$ as an inducer and, in general, satisfactory reproductive performance is observed. For protocols based on weaning day, the main hormone used is analog of gonadotropin-releasing hormone such as triptorelin and buserelin. Regardless of the protocol, the number of piglets born is usually not affected by FTAI. However, a possible compromise in the farrowing rate should be considered. The FTAI in gilts requires progestogen treatment for estrus synchronization, increasing the labor requirement and cost of protocol. Some of the benefits of FTAI are a reduced number of semen doses required, advantage of planning the breeding time and; consequently, optimizing labor involved. However, the limitations include a slight reduction in the fertility index due to the compromised farrowing rate in some cases, costs incurred by following the protocol, and difficulty in measuring all the conceptual benefits under commercial conditions. The aim of this review is to approach the reproductive performance of the current protocols of FTAI, considering the benefits and limitations of this technology in swine production.

Key words: ovulation, synchronization, single insemination, sows, gilts.

Desempenho reprodutivo da inseminação artificial em tempo fixo em suínos e fatores para o sucesso da tecnologia

RESUMO: A inseminação artificial em tempo fixo (IATF) surge como uma biotecnologia para definir o melhor momento para realizar uma única IA, reduzindo o número de células espermáticas por fêmea inseminada. Os protocolos de IATF podem se basear na detecção do estro ou na data de desmame e têm como objetivo sincronizar a ovulação a partir do uso de indutores da ovulação. Protocolos baseados na detecção de estro comumente utilizam o hormônio luteinizante suíno $(p L H)$ como indutor e, de maneira geral, resultados satisfatórios têm sido observados quanto à performance reprodutiva. No caso dos protocolos baseados na data de desmame, os principais hormônios utilizados são os análogos do hormonio liberador de gonadotrofina: triptorelina e buserelina. Independentemente do protocolo, o número de nascidos totais normalmente não é afetado pelo uso da IATF. Porém, um possível comprometimento na taxa de parto deve ser considerado. Já a aplicação da IATF em leitoas requer o fornecimento de um progestágeno, para sincronização do estro, aumentando o manejo e o custo do protocolo. A IATF pode proporcionar diversos beneficios para a indústria suinicola, uma vez que é possivel reduzir o número de doses de sêmen produzidas, melhorar o planejamento de coberturas e, consequentemente, otimizar a mão de obra. No entanto, essa biotecnologia apresenta limitações devendo ser considerado a redução nos dados de fertilidade, uma vez que a taxa de parto pode ser comprometida em alguns casos e, o custo do protocolo e a dificuldade de estimar todos os beneficios conceituais da IATF quando aplicada sob condições comerciais. O objetivo dessa revisão é abordar o desempenho reprodutivo dos mais recentes protocolos de IATF, considerando os beneficios e as limitações dessa tecnologia na produção de suínos.

Palavras-chave: ovulação, sincronização, única inseminação, porcas, leitoas.

\section{INTRODUCTION}

Artificial insemination (AI) is the most common technology in swine reproduction and it has been exhibiting extensive uses worldwide over the last few decades (BORTOLOZZO et al., 2015). It is estimated that more than $90 \%$ of sows are artificially inseminated in countries with technician production systems (RIESENBECK et al., 2011). The focus of the research on AI in swine has been related to the technologies in semen processing and strategies to reduce number of sperm cells per sow bred (BORTOLOZZO et al., 2015; KIRKWOOD \& KAUFFOLD, 2015).

Because of the duration of ovulation in swine (1-4 h; SOEDE, 1993), viability of the oocytes 
(1.2-6.3 h; SOEDE et al., 1992), and the lifespan of sperms in the uterus ( 24h; SOEDE et al., 1995), AI protocols consider insemination until $24 \mathrm{~h}$ before ovulation as the optimal time to obtain a good fertility (KEMP \& SOEDE, 1997; BENNEMANN et al., 2005). Ovulation takes place on average $70 \%$ through estrus, but there is a huge variation in the estrusovulation interval (8-85 h; KEMP \& SOEDE, 1997), making it difficult to predict the ovulation time. For this reason, swine female needs to be inseminated two to three times while in standing estrus. However, only a single insemination is enough for fertilization. If fixed-time artificial insemination (FTAI) is adopted, including hormones to synchronize ovulation and the insemination time, making it possible to determine an appropriate time to perform a single $\mathrm{AI}$, thus reducing labor and number of inseminations required per sow bred. The low rate of FTAI application in the swine industry could be mainly explained by a slight reduction in the fertility index and the costs of the hormonal protocols. Therefore, the aim of this review is to approach the current protocols of FTAI, focusing on their consequences on reproductive parameters and considering the benefits and limitations of this technology in swine production.

\section{Ovulation time}

As described earlier, a large variation in the interval between estrus onset and ovulation is observed. Sows with a weaning-to-estrus interval of three to seven days exhibit an estrus onsetovulation interval of 10 to $58 \mathrm{~h}$ (SOEDE et al., 1995); whereas, gilts show this period to be 16 to $56 \mathrm{~h}$ long (BORTOLOZZO et al., 2005). Estrus duration has a positive correlation with the interval between estrus onset and ovulation (KEMP \& SOEDE, 1996). However, this information is retrospective, making difficult the use of this parameter to predict the ovulation time. For these reasons, variation in the ovulation time is a limiting factor for performing a single AI in swine.

Because of a high degree of variation that exists between the estrus onset and ovulation, it is necessary to use hormones that induce ovulation resulting in a successful FTAI. Therefore, FTAI protocols need the synchronization of ovulation with exogenous hormones that induce a luteinizing hormone (LH) surge, eventually optimizing the time of administration of a single AI.

\section{Synchronization of ovulation in swine \\ Many hormones can be used to control the ovulation in swine (DE RENSIS \& KIRKWOOD,}

2016) and the gonadotropin-releasing hormone $(\mathrm{GnRH})$ analogs have been extensively used as ovulation inducers in FTAI protocols. These act on the hypophysis, inducing the release of LH (BRÜSSOW et al., 1996). The main GnRH analogs commercially used for ovulation induction in pigs are triptorelin and buserelin, and the differences between the two are mainly related to route and time of administration according to the protocol of synchronization (KNOX et al., 2011; DRIANCOURT et al., 2013; KIRKWOOD \& KAUFFOLD, 2015).

Intravaginal administration can be performed with triptorelin at $96 \mathrm{~h}$ post-weaning, and ovulation is induced in $80.1 \%$ of the treated sows between 40 and $48 \mathrm{~h}$ after the application (KNOX et al., 2017a). The protocol for buserelin involves an intramuscular (IM) administration of $10 \mu \mathrm{g}$ between 86 and $89 \mathrm{~h}$ post-weaning, resulting $98.3 \%-100 \%$ of the sows ovulating until $56 \mathrm{~h}$ following the administration (DRIANCOURT et al., 2013; BARONCELLO et al., 2017).

Porcine luteinizing hormone $(\mathrm{pLH})$ is an alternative used for inducing ovulation. The protocol using pLH in sows recommends an application of $5 \mathrm{mg}$ pLH (IM), 80h post-weaning to achieve $90 \%$ of sows ovulating until $40 \mathrm{~h}$ post-application (CASSAR et al., 2005). Despite this result, when $5 \mathrm{mg}$ pLH IM was administrated at estrus onset, ovulation was not anticipated (FONTANA et al., 2014). DEGENSTEIN et al. (2008) used $5 \mathrm{mg}$ pLH, 750UI human chorionic gonadotropin (hCG), and saline $80 \mathrm{~h}$ after administering 600UI equine chorionic gonadotropin (eCG) in gilts pretreated with altrenogest. Results showed that the ovulation time of gilts treated with pLH (35.6-52.1h) had less variation $(\mathrm{P}<0.01)$ compared with the saline-treated (36.1-83.8h) and hCG treated groups $(36.2-67.3 \mathrm{~h})$. Recently, ULGUIM et al. (2016) reported that pLH $(2.5 \mathrm{mg}$ vulvar submucosal route) anticipated the ovulation time in relation to the onset of estrus compared with control group (36.3 and $42.3 \mathrm{~h}$, respectively).

\section{Protocols and results of FTAI in gilts}

The use of a progestogen, such as altrenogest, is necessary in gilts for estrus synchronization before synchronization of ovulation (MARTINAT-BOTTÉ et al., 2010). In pubertal gilts, a daily dose of altrenogest $(20 \mathrm{mg} / \mathrm{d})$ is administered orally for 14 to 18 days for estrus synchronization, and $93 \%$ of gilts are expected to show signs of estrus between 5 and 7 days after altrenogest withdrawal (MARTINAT-BOTTÉ et al., 1995). Ovulation is synchronized in more than $88 \%$ of animals between 
144 and $168 \mathrm{~h}$ post-altrenogest withdrawal, when buserelin $(10 \mu \mathrm{g}$; IM) is administered 104 or $120 \mathrm{~h}$ after the withdrawal of altrenogest (MARTINATBOTTÉ et al., 2010). Studies using triptorelin intravaginally 120 to $140 \mathrm{~h}$ after withdrawing progestogen and performing a single AI $24 \mathrm{~h}$ following inducer administration have also reported decreased estrus-ovulation interval based on the triptorelin administration time (KNOX et al. 2017b; KNOX et al., 2018).Although, effectiveness of altrenogest has been proven to control estrus cycles in swine, the labor for application and duration of the treatment increase costs and may limit the use of FTAI in gilts. Therefore, it is important to research and evaluate alternatives to improve the use of progestogens in commercial FTAI protocols.

FTAI protocols for gilts have also been proposed without the altrenogest treatment, using pLH (vulvar submucosal route) at estrus onset and performing a single insemination $16 \mathrm{~h}$ later. The adjusted farrowing rate was similar to that in the control; however, the total number of piglets born was reduced when $2.5 \mathrm{mg}$ pLH was administered by vulvar submucosal route (12.3 vs. 14.1; ULGUIM et al., 2014). When insemination was performed $12 \mathrm{~h}$ after $\mathrm{pLH}$ application, there was a reduction in the adjusted farrowing rate $(86.0 \%)$ compared with control $(93.5 \%)$. The total number of piglets born was not affected by the treatment but was reported to be lower in the FTAI group when insemination was performed outside the optimal interval (10.5) compared with those inseminated within the optimal time (13.0) (ULGUIM et al., 2016). It is important to emphasize that in the protocols using $\mathrm{pLH}$ at estrus onset for gilts, estrus detection is performed multiple times per day, which is commercially impractical.

\section{Protocols and results of FTAI in sows}

Considering the protocols based on estrus detection, $\mathrm{pLH}$ is the most commonly used ovulation inducer and a single or double insemination can be performed. No impact on reproductive parameters such as the farrowing rate and the total number of piglets born was observed by performing two inseminations in synchronized sows compared with that in the control group (ZAK et al., 2009; ZAK et al., 2010). Even the use of a single insemination after $\mathrm{pLH}$ application did not affect the farrowing rate as well as the total number of piglets born (ULGUIM et al., 2016). FONTANA et al. (2014) observed no differences in the farrowing rate $(90.0$ vs. $93.0 \%)$ and total number of piglets born (12.4 vs. 12.5) when compared single and double FTAI in weaned multiparous sows receiving $\mathrm{pLH}$ at the estrus onset.

Protocols considering estrus onset for ovulation induction have benefits in terms of reduction in the number of semen doses and handling involved in performing $\mathrm{AI}$ on consecutive days, producing satisfactory results in reproductive performance. However, detecting estrus and administering hormones should be performed daily. In addition, it is also important to consider that $\mathrm{pLH}$ is a biological molecule with limitations in the manufacturing process.

In protocols based on the day of weaning, differences in the time of hormonal application after weaning and in estrus detection are observed in the protocols using triptorelin or buserelin. Originally, in the triptorelin protocol, it was suggested that no estrus detection should have to be performed and all weaned sows were subjected to hormonal treatment (96h postweaning) and inseminated until day 7 post-weaning, regardless of estrus expression. In this way, a new metric of comparison was structured and defined as the farrowing efficiency (number of sows farrowed/ number of sows weaned; KRAELING \& WEBEL, 2015). Using this concept and performing two inseminations ( 8 and $36 \mathrm{~h}$ after triptorelin injection; KNOX et al., 2011) or a single insemination (22-24h post-treatment; WEBEL et al., 2014), the farrowing efficiency and the total number of piglets born have been reported with no differences. A meta-analysis was performed including the studies from 2008 to $2015(\mathrm{n}=5,238)$, in which the triptorelin protocol was followed in weaned sows, and the traditional farrowing rate was observed to be superior in the control group, compared with that in the triptorelininduced sows $(89.7 \%$ vs. $82.5 \%)$. However, greater farrowing efficiency was verified in the group treated with triptorelin $(82.5 \%)$ than that in the control group $(80.1 \%)$. The numbers of total piglets born were similar in both the groups (ROSTAGNO et al., 2016).

In the buserelin protocol, estrus detection is recommended to determine females to be subjected to hormone administration and insemination, as suggested by MARTINAT-BOTTÉ et al. (2010). Buserelin is administered $86 \mathrm{~h}$ post-weaning and a single insemination is performed 30 to $33 \mathrm{~h}$ later, excluding from the FTAI protocol sows in estrus within $72 \mathrm{~h}$ post-weaning and animals that do not show any signs of estrus at the time scheduled for AI. The farrowing rate $(87.0 \%$ vs. $84.5 \%)$ and the total number of piglets born (13.6 vs. 13.7$)$ in the FTAI group were similar to that in the group wherein 
sows were inseminated multiple times, respectively (DRIANCOURT et al., 2013). BARONCELLO et al. (2017) observed a reduction in the adjusted farrowing rate using buserelin $(83.9 \%)$ and its use in combination with eCG $(76.4 \%)$, by performing a single FTAI regardless of estrus expression, compared with the control group (95.7\%). No differences in the adjusted farrowing rate and the total number of piglets born were observed among the groups when insemination was performed only in sows expressing estrus signs at the time of insemination (BARONCELLO et al., 2017). Currently, under field conditions, it has been suggested to breed only sows showing estrus signs at the time of conducting FTAI for triptorelin protocols.

Using boars in FTAI protocols could be considered practical not only in identifying sows to be inseminated but also because an improvement in the ovulation induction is achieved. According to ULGUIM et al. (2018), boar exposure from the day after weaning increases the proportion of sows ovulating until $48 \mathrm{~h}$ post-triptorelin administration $(77.7 \%)$ compared with weaned sows subjected to no boar exposure after weaning $(67.5 \%)$. There was also a tendency of more sows being inseminated within an optimal time period when boar exposure was carried out. Protocols for FTAI in swine are better described in DE RENSIS \& KIRKWOOD (2016) and results obtained from main protocols in the last years are summarized in table 1 .

\section{Key factors for the success of FTAI programs}

The success of FTAI protocols is highly dependent on the synchronization of ovulation and inseminations performed within the optimal time period to obtain better fertility. According to BARONCELLO et al. (2017), a lower adjusted farrowing rate was observed in sows inseminated once outside the optimal interval (21\%) after buserelin application compared with those inseminated within the optimal time $(91.4 \%)$.

Insemination in sows not in estrus can also increase the possibility of vulvar discharges due to low cellular immunity in the endometrium during the metestrus phase (KAEOKET et al., 2003). In protocols wherein daily estrus detection is not performed, it is important to take into account the possibility of inseminating sows that are not in estrus. An alternative for this situation is to carry out estrus detection at the time of FTAI to inseminate only those animals expressing estrus behavior. The use of buserelin resulted in approximately $92 \%$ (DRIANCOURT et al., 2013; BARONCELLO et al., 2017) of animals exhibiting estrus at the time of FTAI. In this way, the use of this technology should consider the percentage of sows to be subjected to FTAI and those in which the traditional protocol must be used, minimizing the reduction on reproductive parameters.

The occurrence of semen backflow when a single insemination was conducted was correlated with a lower chance of weaned sows becoming pregnant (FONTANA et al., 2014). The reduction in the farrowing rate was reported in gilts subjected to a single FTAI when the nonoccurrence (94.9\%) was compared with the occurrence $(50 \%)$ of semen backflow during insemination (ULGUIM et al., 2016). In the same study, the total number of piglets born was negatively affected both in gilts (11.2 vs. 13.6) and weaned sows (10.4 vs. 12.5) that showed semen backflow during insemination compared with females in which semen backflow was not observed. Thus, it is recommended to repeat the insemination immediately in animals exhibiting semen backflow during the process (FONTANA et al., 2014).

The number of sperm cells in a semen dose is another criterion that should be investigated. KNOX et al. (2017a) evaluated the use of 1.5 or 2.5 billion sperms by performing a single post-cervical AI in weaned sows. The authors observed an increased litter size when 2.5 billion sperms were used as compared with 1.5 billion sperms, with no difference in the farrowing rates. However, the minimum number of sperm cells that results in a good fertility rate using FTAI as well as the storage time of a semen dose remains unclear. Another important element is the presence of sub-fertile boars in the herd, which can negatively affect the reproductive performance. It is difficult to identify such boars, thus, reproductive fertility might be affected by the lack of identification and use of such boars in a FTAI program.

\section{Prospects of using FTAI in swine}

Conceptually, FTAI has several benefits for the swine industry. In boar studs, the use of a single FTAI reduces the number of semen doses required, thus reducing the number of boars in the boar inventory. Consequently, less labor for semen production is involved and the possibility to increase investments in high-index boars would be obtained. The possibility of prediction of the number of females to be inseminated reduces the wastage of semen doses orders, optimizing the use of doses with less period of storage. Handling for insemination and estrus detection are also reduced, allowing increased focus during insemination procedures. FTAI programs could also improve the farrowing concentration, 
Table 1 - Reproductive performance obtained from protocols used for FTAI in sows and gilts.

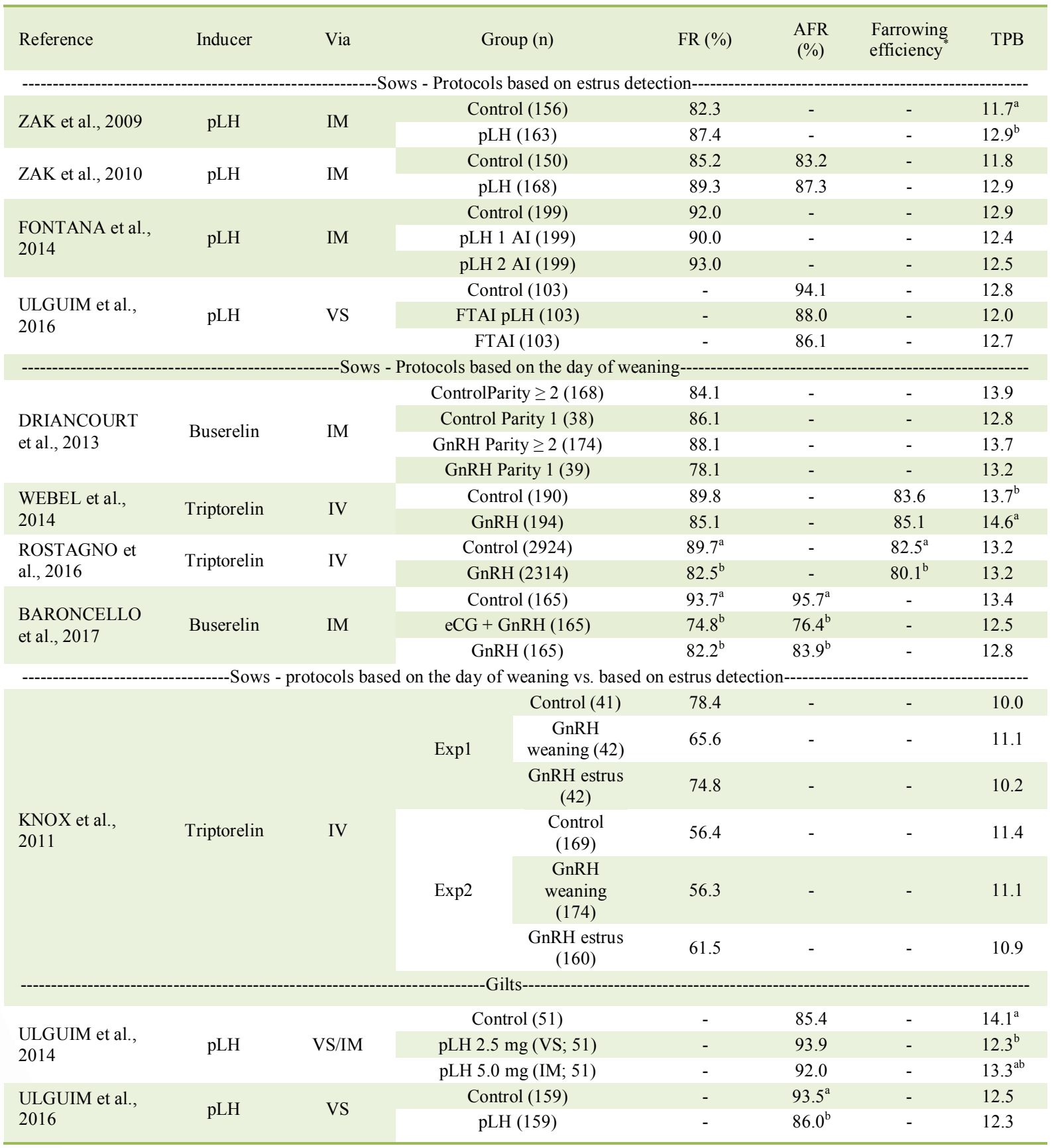

FR: Farrowing rate; AFR: Adjusted farrowing rate; TPB: total number of piglets born; IV: intravaginally; SV: vulvar submucosal ${ }^{*}$ number of sows farrowed/number of sows weaned.

$\mathrm{a}, \mathrm{b}$ in the column indicate significant difference among the groups $(\mathrm{P}<0.05)$.

with a positive impact on farrowing assistance and contributing to the uniformity of weaning age and lactation period. Although, cited as a possibility, these benefits need to be studied extensively.
The biggest challenges in the practical application of FTAI are those related to the possibility of a reduction in the farrowing rate due to certain protocols and field observations. It is essential to be 
aware of the necessity to perform the traditional AI protocol in sows with a weaning-to-estrus interval of up to three days, as well as in females that do not exhibit estrus at the time of FTAI. Additionally, the cost of hormonal protocol remains high, especially for gilts.

\section{CONCLUSION}

Development of new drugs and protocols, advancements in swine industry have improved the reproductive performance of FTAI which have shown promising results over the last few years. Although, the farrowing rate can be affected in some cases, the total number of piglets born is not usually affected by the protocol. However, the cost of the hormonal protocol is still high, especially that for gilts. Although, this technology is very beneficial for swine production, it is difficult to measure all their conceptual benefits in a commercial setup, due to the cost of the protocol and lack of knowledge on the returns on investment.

\section{ACKNOWLEDGMENTS}

The authors are thankful to Conselho Nacional de Desenvolvimento Científico e Tecnológico (CNPq) and Coordenação de Aperfeiçoamento de Pessoal de Nível Superior - Brasil (CAPES) for the scholarships provided. F.P. Bortolozzo received a Productivity Fellowship from the CNPq (304342/2016-5).

\section{DECLARATION OF CONFLICTING INTERESTS}

The authors declare no conflict of interest. The founding sponsors had no role in the design of the study; in the collection, analyses, or interpretation of data; in the writing of the manuscript, and in the decision to publish the results.

\section{AUTHORS' CONTRIBUTIONS}

All authors contributed equally for the conception and writing of the manuscript. All authors critically revised the manuscript and approved the final version.

\section{REFERENCES}

BARONCELLO, E. et al. Fixed-time postcervical artificial insemination in weaned sows following buserelin use combined with/without eCG. Reproduction in Domestic Animals, v. 52, p. 76-82, 2017. Available from: <https:/www.ncbi.nlm.nih. gov/pubmed/27696569>. Accessed: Apr. 09, 2018.doi: 10.1111/ rda. 12805 .

BENNEMANN, P. E. et al. Artificial insemination of gilts with 1.5 billion sperms stored in dierent periods associated with dierent pre-ovulatory intervals. Reproduction in Domestic Animals, v. 40 , p. $507-510,2005$. Available from: <https://www.ncbi. nlm.nih.gov/pubmed/16324074>. Accessed: Apr. 09, 2018. doi: 10.1111/j.1439-0531.2005.00614.x.

BORTOLOZZO, F. P. et al. New artificial insemination technologies for swine. Reproduction in Domestic Animals, v. 50, p. $80-84,2015$. Available from: $<$ https://onlinelibrary.wiley. com/doi/pdf/10.1111/rda.12544>. Accessed: Apr. 12, 2018.doi: $10.1111 /$ rda. 12544 .

BORTOLOZZO, F. P. et al. Influence of time of insemination relative to ovulation and frequency of insemination on gilt fertility. Theriogenology, v. 64, p. 1956-1962, 2005. Available from: $<$ https://www.ncbi.nlm.nih.gov/pubmed/16005953>. Accessed: Jul. 09, 2018. doi: 10.1016/j.theriogenology.2005.04.023.

BRÜSSOW, K. P et al. Control of ovulation with a GnRH analog in gilts and sows. Theriogenology, v. 46, p. 925-934, 1996. Available from: <https:/www.sciencedirect.com/science/article/ pii/S0093691X96002580>. Accessed: Apr. 09, 2018. doi:10.1016/ S0093-691X(96)00258-0.

CASSAR, G. et al. Effect of single or double insemination on fertility of sows bred at an induced estrus and ovulation. Journal of Swine Health and Production, v. 13, p. 254-258, 2005. Available from: $<$ https://www.aasv.org/shap/issues/v13n5/v13n5p254>. Accessed: Apr. 09, 2018.

DE RENSIS, F; KIRKWOOD, R. N. Control of estrus and ovulation: Fertility to timed insemination of gilts and sows. Theriogenology, v. 86, p. 1460-1466, 2016. Available from: < https://www.sciencedirect. com/science/article/pii/S0093691X16301893?via\%3Dihub>. Accessed: Oct. 30, 2018. doi:10.1016/j.theriogenology.2016.04.089.

DEGENSTEIN, K. L. et al. Synchronization of ovulation in cyclic gilts with porcine luteinizing hormone $(\mathrm{pLH})$ and its effects on reproductive function. Theriogenology, v. 70, p. 1075-1085, 2008. Available from: <https://www.ncbi.nlm.nih. gov/pubmed/18656251>. Accessed: Apr. 10, 2018. doi: 10.1016/j. theriogenology.2008.06.027.

DRIANCOURT, M. A. et al. Induction of an LH surge and ovulation by buserelin (as Receptal) allows breeding of weaned. sows with a single fixed-time insemination. Theriogenology, v. 80, p. 391-399, 2013. Available from: <https:/www.ncbi.nlm.nih. gov/pubmed/23777891>. Accessed: Apr. 10, 2018. doi: 10.1016/j. theriogenology.2013.05.002.

FONTANA, D. L. et al. Fixed-time post-cervical artificial insemination in sows receiving porcine luteinizing hormone at oestrus onset. Animal Reproduction Science, v. 144, p. 109-114, 2014. Available from: <https:/www.ncbi.nlm.nih.gov/ pubmed/24418126>. Accessed: Apr. 12, 2018.doi: 10.1016/j. anireprosci.2013.12.003.

KAEOKET, K. et al. Influence of pre-ovulatory insemination and early pregnancy on the infiltration by cells of the immune system in the sow endometrium. Animal Reproduction Science, v. 75, p. 55-71, 2003. Available from: <https://www.sciencedirect.com/ science/article/pii/S0378432002002300?via\%3Dihub>. Accessed: Apr. 10, 2018. doi:10.1016/S0378-4320(02)00230-0.

KEMP, B.; SOEDE N. M. Consequences of variation in interval from insemination to ovulation on fertilization in pigs. Journal of Reproduction and Fertility Supplement, v. 52, p.79-89, 1997. Available from: <https://www.ncbi.nlm.nih.gov/pubmed/9602721>. Accessed: Apr. 18, 2018. 
KEMP, B.; SOEDE, N. M. Relationship of weaning-to-estrus interval to timing of ovulation and fertilization in sows. Journal of Animal Science, v. 74, p. 944-949, 1996. Available from: <https:// academic.oup.com/jas/article/74/5/944/4624752>. Accessed: Apr. 13, 2018. doi: $10.2527 / 1996.745944 x$.

KIRKWOOD, R. N.; KAUFFOLD, J. Advances in breeding management and use of ovulation induction for fixed-time AI. Reproduction in Domestic Animals, v. 50, p. 85-89, 2015. Available from: <https://www.ncbi.nlm.nih.gov/ pubmed/26174924>. Accessed: Jul. 09, 2018.doi: 10.1111/ rda. 12524 .

KNOX, R. V. et al. Design and biological effects of a vaginally administered gel containing the GnRH agonist, triptorelin, for synchronizing ovulation in swine. Theriogenology, v. 112, p. 44-52, 2018. Available from: <https://www.ncbi.nlm.nih.gov/ pubmed/28863964>. Accessed: Apr. 20, 2018.doi: 10.1016/j. theriogenology.2017.08.021.

KNOX, R. V. et al. Effect of numbers of sperm and timing of a single, post-cervical insemination on the fertility of weaned sows treated with $\mathrm{OvuGel}^{\circledR}$.Theriogenology, v.92, p. $197-$ 203, 2017a. Available from: <https://www.ncbi.nlm.nih.gov/ pubmed/28237336>. Accessed: Apr. 10, 2018. doi: 10.1016/j. theriogenology.2017.01.033.

KNOX, R. V. et al. Effects of estrus synchronization using Matrix ${ }^{\circledR}$ followed by treatment with the $\mathrm{GnRH}$ agonist triptorelin to control ovulation in mature gilts. Animal Reproduction Science, v. 185, p. 66-74, 2017b. Available from: $<$ https://www.sciencedirect.com/ science/article/pii/S0378432017304657?via\%3Dihub>. Accessed: Apr. 10, 2018. doi:10.1016/j.anireprosci.2017.08.003.

KNOX, R. V. et al. Synchronization of ovulation and fertility in weaned sows treated with intravaginal triptorelin is influenced by timing of administration and follicle size. Theriogenology, v. 75, p. 308-319, 2011. Available from: <https://www.ncbi.nlm.nih. gov/pubmed/21040957>. Accessed: Apr. 10, 2018. doi: 10.1016/j. theriogenology.2010.09.001.

KRAELING, R. R.; WEBEL, S. Current strategies for reproductive management of gilts and sows in North America. Journal of Animal Science and Biotechnology, v. 6, p. 1-14, 2015. Available from: $<$ https://www.infona.pl/resource/bwmeta1. element.springer-da02433a-227e-39c6-ba6c-f6a5775a957a>. Accessed: Apr. 10, 2018.doi: 10.1186/2049-1891-6-3.

MARTINAT-BOTTÉ, F. et al. Induction and synchronization of ovulations of nulliparous and multiparous sows with an injection of gonadotropin-releasing hormone agonist (Receptal). Theriogenology, v. 73, p. 332-342, 2010. Available from: $<$ https:// www.ncbi.nlm.nih.gov/pubmed/19962182>. Accessed: Apr. 10, 2018. doi: 10.1016/j.theriogenology.2009.09.017.

MARTINAT-BOTTÉ, F. et al. Synchronization of oestrus in gilts with altrenogest: effects on ovulation rate and foetal survival. Animal Reproduction Science, v. 39, p. 267-274, 1995. Available from: <https://www.sciencedirect.com/science/ article/pii/037843209501396H>. Accessed: Apr. 10, 2018. doi:10.1016/0378-4320(95)01396-H.

RIESENBECK, A. Review on international trade with boar semen. Reproduction in Domestic Animals, v. 46, p. 1-3, 2011. Available from: $\quad<$ https://www.ncbi.nlm.nih.gov/pubmed/21884268>.
Accessed: Apr. 10, 2018. doi: 10.1111/j.1439-0531.2011.01869.x. ROSTAGNO, M. et al. The impact of ovugel on reproductive performance of weaned sows. In: 24th International Pig Veterinary Society Congress, 8th European Symposium of Porcine Health Management, 2016. Posters Abstract. Dublin, Irlanda. Royal Dublin Society, 2016.p. 378.

SOEDE, N. M. et al. Effects of time of insemination relative to ovulation, as determined by ultrasonography, on fertilization rate and accessory sperm count in sows. Journal of Reproduction and Fertility, v. 104, p 99-106, 1995. Available from: <https://www. ncbi.nlm.nih.gov/pubmed/7636812>. Accessed: Apr. 09, 2018. doi: 10.1530/jrf.0.1040099.

SOEDE, N. M. Boar stimuli around insemination affect reproductive processes in pigs: A review. Animal Reproduction Science, v. 32, p. 107-125, 1993. Available from: $<$ https://www.sciencedirect.com/ science/article/pii/037843209390062V>. Accessed: Apr. 09, 2018. doi: 10.1016/0093-691X(93)90005-P.

SOEDE, N. M. et al., The duration of ovulation in pigs, studied by transrectal ultrasonography is not related to early embryonic diversity. Theriogenology, v. 38, p. 653-666, 1992. Available from: $<$ https://www.ncbi.nlm.nih.gov/pubmed/16727168>. Accessed: Apr. 09, 2018. doi:10.1016/0093-691X(92)90028-P.

ULGUIM, R. R. et al. Ovulation and fertility responses for sows receiving once daily boar exposure after weaning and OvuGel ${ }^{\circledR}$ followed by a single fixed time post cervical artificial insemination. Theriogenology, v. 105, p. 27-33, 2018. Available from: <https:// www.ncbi.nlm.nih.gov/pubmed/28917726>. Accessed: Apr. 12, 2018.doi: 10.1016/j.theriogenology.2017.09.005.

ULGUIM, R. R.et al. Single fixed-time artificial insemination in gilts and weaned sows using pLH at estrus onset administered through vulvar submucosal route. Theriogenology, v. 86, p. 1072-1080, 2016. Available from: <https://www.ncbi.nlm.nih. gov/pubmed/27157392>. Accessed: Apr. 10, 2018. doi: 10.1016/j. theriogenology.2016.03.039.

ULGUIM, R. R. et al. Use of porcine luteinizing hormone at oestrous onset in a protocol for fixed-time artificial insemination in gilts. Reproduction in Domestic Animals, v. 49, p. 756 760, 2014. Available from: <https://www.ncbi.nlm.nih.gov/ pubmed/25130264>. Accessed: Apr. 10, 2018.doi: 10.1111/ rda. 12362 .

WEBEL, S. et al. Commercial farm evaluation of sow reproductive performance using OvuGel ${ }^{\circledR}$ with a single fixed-time artificial insemination protocol. In: AASV Annual Meeting: Our Oath in Practice, 2014, Dallas, Texas. Poster. 45th Annual Meeting of the American Association of Swine Veterinarians, 2014a.p. 469-470.

ZAK, L. J. et al. Benefits of synchronizing ovulation with porcine luteinizing hormone in a fixed-time insemination protocol in weaned multiparous sows. Journal of Swine Health and Production. v. 18, p. 125-131, 2010. Available from: <https://www.aasv.org/shap/ issues/v18n3/v18n3p125.pdf $>$. Accessed: Apr. 12, 2018.

ZAK, L. J. et al. Benefits of synchronizing ovulation with porcine luteinizing hormone $(\mathrm{pLH})$ in a fixed time insemination protocol in weaned multiparous sows. Society of Reproduction and Fertility Supplement, v. 66, p. 305-306, 2009. Available from: $<$ https://www.ncbi.nlm.nih.gov/pubmed/19848297>. Accessed: Apr. 12, 2018. 